\title{
How to cover
}

\section{those summer reference hours}

\author{
A novel approach to the nine-month contract \\ at an academic library
}

by Scott Lanning

$\mathrm{A}$ t Southern Utah University (SUU), ninemonth contracts and faculty status are the standard for librarians. This is considered one of the best benefits of the job, but it leaves the library without summer coverage of the reference desk. Every year, faculty members must be recruited to work in the summer. To get employees to give up some portion of their vacation, additional salary-known as overload-is paid. This has been the practice for many years.

The lure of additional money is attractive to many faculty, but no one wants to give up his or her entire vacation. This situation requires that a large percentage of the faculty be employed for short periods of time in a variety of schedules to ensure full reference desk coverage, even though the reference desk is staffed only five hours a day on summer weekdays versus eleven hours a day during fall and spring.

Summer scheduling and contract writing is a great deal of work, with no guarantee of reaching the necessary coverage. In addition, a substantial amount of money must be included in the operating budget to cover overload. The system worked for SUU, but we wanted something better.

Our solution was to shift the schedules of two faculty members. Their schedules now include the summer months, with one fac- ulty member getting the equivalent amount of time off in the spring and the other getting time off in the fall.

This gives the library the reference desk coverage it needs for the summer, with one morning shift of two hours and one afternoon shift of three hours.

\section{Recruiting to the new schedule}

While the intrinsic value of the schedule holds appeal to some faculty, it does not appeal to others. Faculty with children in school are not as likely to be interested in this schedule, as they prefer to have the summers off with their children. Faculty with spouses who are also faculty are not likely to be interested because they will not have the same time off. However, the lure of time off in the spring or fall is very attractive to faculty who do not have these obligations.

\section{Advantages of the new schedule}

The most obvious advantage of the shifted schedules is coverage of the reference desk during the summer and the end of the annual recruiting and scheduling headache. That onerous task has been eliminated.

Another advantage is that more money for overloads is freed by these schedules. Previously, a large percentage of our overload went towards summer coverage, with the rest go-

\section{About the author}

Scott Lanning is public services librarian at Southern Utah University in Cedar City, e-mail: lanning@suu. edu 
ing toward special projects. At some institutions, the salary savings could be used for other purposes, such as pay raises.

A less obvious aclvantage is morale. These new schedules are certainly a boost for those who got them, but there is also much less pressure on the other faculty to work during the summer months.

\section{Disadvantages of the new schedule}

Coverage is the biggest clisadvantage. If your spring and fall coverage would suffer or if the loads on remaining faculty would be too heavy, then this schedule cannot be attempted. By staggering the new scheclules, we are only down one person in fall and spring. Faculty will be working more reference desk hours during those semesters, although this increase is relatively small compared to the increase in reference desk hours the summer employees will work. On an annual basis, they will be working many more reference hours than their traditionally scheduled colleagues. However, these hours traditionally receive fewer questions than fall and spring reference hours.

Another disadvantage is missing committee meetings and having fewer opportunities to interact with colleagues. Membership on campus and statewide committees is expected of faculty, and a good solution to this situation has not been worked out, but committee sharing may be a possibility for some committees.

For those faculty on the traditional schedule, there may be a perception of fewer overload oppontunities (thus less salary), due to the lack of need for summer reference desk coverage. In the past, a faculty member could combine a special project with reference work. Since reference coverage was always needed, this approach to summer projects was typical. Now, with coverage no longer the issue, the project is paramount. This shift may move more of the overload to departments that are projectoriented, like cataloging.

\section{Conclusion}

Overall, we believe this program will be beneficial to our library. It gives us consistent coverage at the reference clesk for all future summers. Originally, only one position was going to have the shifted schedule, but a second employee lobbied the admin- istration on the benefits of two employees. One faculty member could not work all of the hours on the reference desk, so recruiting as in past years would have had to continue, but two faculty members could handle all of the hours.

\section{Perfect timing}

The timing of our decision seems fortuitous. With our schedules and contracts in place for the upcoming year, we learned that the university is changing the way overload is distributed.

Departments will no longer have their own pool of money. Instead, the university will pool all the overload, and each faculty member in each department will have to compete for that money. This would have been disastrous for the library, but by changing our schedules now to ensure necessary coverage of the reference desk in the summer, we heacled off being forced into making essentially the same changes next year.

While the outcome of a forced change may have been the same, it would not have been as happy as our voluntary program.

\section{Letter to the editor}

Orchicls to CERL News for publishing Scott R. DiMarco's piece "I know that's what it said, but it's not what we want" (June 2000), and orchids to Scott for mentioning my particular pet peeve as tip $=1$. A perfectly appalling percentage of ads in our profession don't give any hint about the salary range proposed. It's very frustrating for job-hunters, and it probably prevents some good matches from finding each other without waste of time.

Onions to the copy editor who passed "Awareness of current academic trends that effect library operations" (p. 504). That should be "affect." "Effect" for completive, "affect" for incremental. Usages are slipping all around us, but let's hold the line on that one for a bit longer, if we can.

Great piece, though. I hope HR officers read it, and mend their ways. - Christopher H. Walker, Indiana University, e-mail: chwalker@indiana.edu 